\title{
Microbial degradation of plastic-A brief review
}

Sumaira Mazhar ${ }^{*}$, Hafiza Akifa Naeem ${ }^{1}$ and Muneeba Naheed ${ }^{1}$

1. Department of Biology, Lahore Garrison University Sector C Phase 6 DHA Lahore, Pakistan

*Corresponding author's email: smz.mmg@gmail.com

Citation

Sumaira Mazhar, Hafiza Akifa Naeem and Muneeba Naheed. Microbial degradation of plastic-A brief review. Pure and Applied Biology. Vol. 11, Issue 2, pp446-458. http://dx.doi.org/10.19045/bspab.2022.110044

Received: 22/04/2021

Revised: 19/07/2021

Accepted: 09/08/2021

Online First: 26/08/2021

\section{Abstract}

Wide variety of high molecular weight organic polymers known as plastic is the most common sources of hydrocarbons and petroleum derivatives. Due to excessive industrial and domestic use, plastic is now being used and produced at a very high rate. Except for a few, a large number of polymers are not biodegradable and the main threats to our environment because of its poor waste management, excessive usage and the relaxed behavior of the community against proper disposal. Some policies and advance approaches for plastic waste management include practice of biodegradable polymers in wrapping and public education about their appropriate disposal, are introduced by the investors. Chemical, photo, thermal and biological methods are also involved in the current polymer degradation policies. But for environmental, economic and health advantages; the practice of biodegradable plastics are the attractive options. In the current review, classification of plastics with distinct prominence on the biodegradable plastics and their coherent usage, recognized methods, microbes tangled and the present visions in the research of degradable plastics are highlighted. In the future prospective microbe's friendly plastic is safe for environment and it can reduce the plastic waste from earth. Further studies are under investigation and it will be having great applications in future because of its low cost and environment friendly nature.

Keywords: Biodegradation; Environmental threat; Plastic; Waste management

\section{Introduction}

Plastic is made up of an extensive variety of synthetic/semi-synthetic organic and inorganic substances [1]. The two groups of plastics are thermoplastic and thermoset plastic and there are two basic procedures that cause the production of synthetic polymers. In the first, $\mathrm{C}-\mathrm{C}$ bonds are formed for carbon chains by the breakdown of double bonds by polymerization while in the second procedure; polyester and polyamide are made by the elimination of Water $(\mathrm{H} 2 \mathrm{O})$ between carboxylic acid and amine or alcohol [2]. Plastics that are biodegradable are getting common because of their approachable nature with the environment. There are different forms of biodegradable polymers that are based on starch in which starch is mixed with various different plastics which include polylactic acid (PLA), polycaprolactone polyhydroxybutyrate (PHB) and polybutylene succinate (PBS) [3]. Commonly used plastics are not biodegradable [4]. Besides health and environmental issues, the long-lasting gathering of the plastics that are not biodegradable has lowered the soil 
richness/fertility. Annually 57 million tons' waste of this plastic is produced [5]. Due to this reason, researchers and investors are working to lower the gathering of nonbiodegradable plastics from the environment [6].

\section{Plastics and their practices}

Polyethylene terephthalate (PET) is used for plastic bottles, jars, plastic films, textile fibers and microwavable packaging. Polyethylene (PE) is used commonly as shopping bags and plastic bottles, Polyvinyl chloride (PVC) is used in flooring, shower curtains, plumbing pipes and guttering, Polypropylene (PP) is used in bottle caps, drinking straws, appliances, containers, window frames, Polystyrene (PS) is used in cassette boxes, packaging food, plastic tableware, disposable cups and food containers [7]. Polyvinylidene chloride (PVDC) is used as food packaging, Lowdensity polyethylene (LDPE) is used as floor tiles, shower curtains, and furniture for outdoor, Polyamides (PA) is used in fishing line, car engine molding, fibers and toothbrush bristles, Polyester (PES) in fiber and textiles, Polyetherimide (PEI) is used in electrical insulation, Polylactic acid (PLA) is a biodegradable plastic that can be easily changed into many different aliphatic polyesters resulting from lactic acid and Nylon is used as football, speedometer gears, windshield wipers [8].

\section{Classification of plastics on the basis of biodegradation}

On the basis of biodegradability there are two types of plastic:

\section{Non-biodegradable plastics}

Polymers that are based on fossils and biobased polymers comprise non-biodegradable plastics. Most commonly used are the fossil based synthetic polymers obtained from petrochemicals. They have high molecular weight because of the re-occurrence of monomer units [9]. They include Polyvinyl chloride (PVC), Polypropylene (PP),
Polystyrene (PS), Polyethylene terephthalate (PET), Polyurethane (PUR) and Polyethylene (PE). They have gathered in large numbers in the environment because of improper waste management systems [10].

\section{Biodegradable plastics}

Bio-based and fossil-based polymers comprise biodegradable plastics based upon the level of biodegradation and microbial interaction. It contains enzymatic and nonenzymatic breakdown of water i.e. hydrolysis [11]. Aerobic and anaerobic processes are included in biodegradation [12]. The most used types of bio-based plastics are polyhydroxyalkanoate (PHA) and polylactic Acid (PLA) [13] (Table 1), while polyethylene succinate (PES) [14] and polycaprolactone (PCL) are fossil based plastics [15].

\section{Microplastics and its types}

Microplastic is a worldwide problem because of its detection everywhere [16]. $92.4 \%$ of microplastic is made of plastic waste and mainly contains polystyrene, polyethylene and polypropylene [17]. Polyethylene, Polycaprolactone, polypropylene, polyurethane, polyvinyl chloride, polyethylene terephthalate, polyhydroxy butyrate, polyhydroxy alkanoate, polybutylene succinate, polylactic acid or polylactide, and polystyrene are mostly used [18]. Since 1950, worldwide plastic production has increased continuously and produced worldwide by 6.3 billion tons, in 2015. Nevertheless, the recycled plastic is just 25\% [19], whereas the other is crushed into small trashes and are called microplastics. Currently, microplastics have contaminated rivers, lakes, agricultural land, etc. [20-22].

\section{Complications caused by plastics}

Wildlife and our environment are facing many threats because of these plastics [23]. Some of the issues are the risks to environment, natural life, marine destruction and some of the serious human issues. Every 
year, 5 trillion plastics are used only once, worldwide. This large amount of plastics gets into the oceans and then they become the source of damage to biotic and abiotic machinery of the environment [24, 25]. Animals are dying because of this plastic by eating or being caught in it [26]. They are also destroying marine life, approx. 8 trillion of plastics get mixed into the ocean every year and they remain in the environment for many years because of their resistance to degradation. This plastic is getting into our body by eating the fishes. Hundreds of marine animals are dying because of this plastic annually. According to the researchers, if this trend remains continuous then we'll be having more plastic in the ocean than fishes [25].

These plastics can copy human hormones and this causes human health problems. They are causing certain cancers. According to the International Agency for Research on Cancer (IARC) Vinyl chloride is stated as a cancer causing agent in humans $[27,28]$. Styrene is also highlighted for causing cancer especially for breast cancer [29]. BPA (bisphenol A) is causing premature birth, retardation in growth and stillbirth [30]. It also has the impacts on the sex hormones in females i.e. progesterone [31].

\section{Microbial degradation of plastics}

While finding different ways to lower microplastic pollution, scientists were amazed to know that microplastics can go on in the environment and can be degraded by the microorganisms [10]. Microbes can adopt any environment and they have the ability to degrade different substances that include microplastics [32]. Microbes are used for the degradation of plastics. They perform degradation without damaging the environment [33], creating a safe environmental approach for bioremediation and without creating any opposing effects, it also cleans the natural ecosystem [12]. Currently, only a limited number of microbes have been separated that are functional, but still the relationship between microorganisms and microplastics is not cleared and it is due to the deficiency of information [34]. So, it is important to review and examine the current information to find out how to find microbes that are useful in the microplastic breakdown process and also promote the knowledge of microbial metabolic activity and microplastics usage. The purpose of this review is to classify precisely and examine the new studies related to microbial intermediated degradation of microplastics and also to explain the properties and process of microplastic degradation. Certain fungi, bacteria and biofilms are explained in this article that can degrade microplastics and its certain types which include polyethylene, polypropylene, polyvinyl chloride, polyethylene terephthalate, polyhydroxy butyrate, polyhydroxy alkanoate, polybutylene succinate etc.

\section{Microbial involvement}

Certain microbes are involved in the degradation of plastics. Different physiochemical and degradation factors are involved in the process of microbial degradation of plastics, in certain environments [35]. Alteration of microplastics has largely been affected by microbial degradation even though they are less prone to microbial outbreak than other degradable ingredients [36]. In order to explore the degradation activity of plastics, different types of microorganisms are involved that have been obtained from different environmental samples.

\section{Bacterial degradation of plastic}

Bacteria are the chief set of microbes that are present in large numbers that other organisms. They live in water, soil and atmosphere, and most species are known for their degradable activity against pollutants [37]. Currently, various studies have examined the involvement of bacteria for microplastic degradation. These studies have 
used pure bacterial cultures for this purpose. It is the easiest way for the examination of metabolic ways and the effects of certain environmental circumstances involved in the degradation of plastics. The variations and the whole procedure of plastic degradation by bacteria can be observed [38].

For this purpose, certain plastics were treated with microbes for different time periods under laboratory conditions and different activities of microbes were seen on the surface of the plastics. And the results declared that the pure cultures of bacteria were able to stick, multiply (colony formation) and could also destroy micro plastics and its types. Some of them are discussed below in (Table 1).

Table 1. Bacterial strains involved in degradation of plastics

\begin{tabular}{|c|c|c|c|}
\hline Bacterial strain & Source & Plastic type & Ref. \\
\hline $\begin{array}{c}\text { Rhodococcus, } \\
\text { Bacillus }\end{array}$ & Mangrove sediments & Polypropylene (PP) & [39] \\
\hline Bacillus cereus & Mangrove ecosystems & $\begin{array}{c}\text { Polyethylene, } \\
\text { Polyethylene terephthalate (PET) } \\
\text { and PS }\end{array}$ & \multirow[b]{2}{*}{ [40] } \\
\hline Bacillus gottheilii & Mangrove ecosystems & $\begin{array}{c}\text { Polyethylene, } \\
\text { Polyethylene terephthalate (PET), } \\
\text { Polypropylene and PS }\end{array}$ & \\
\hline Enterobacter asburiae & \multirow{2}{*}{ Plastic eating waxworms } & \multirow{2}{*}{ Polyethylene (PE) } & \multirow{2}{*}{ [41] } \\
\hline Bacillus sp. YP1 & & & \\
\hline $\begin{array}{c}\text { Arthrobacter sp. } \\
\text { GMB5 }\end{array}$ & Gulf Mannar dump sites & $\begin{array}{l}12 \% \text { loss of molecular weight of } \\
\text { plastic }\end{array}$ & [41] \\
\hline Zalerion maritimum & $\begin{array}{l}\text { Marine environment } \\
\text { (Benthic zone) }\end{array}$ & Polyethylene (PE) & [42] \\
\hline $\begin{array}{c}\text { Shewanella, Moritella } \\
\text { sp., Psychrobacter sp., } \\
\text { Pseudomonas sp. }\end{array}$ & $\begin{array}{l}\text { Deep-sea sediment, the } \\
\text { Kurile and Japan Trenches }\end{array}$ & Polycaprolactone (PCL) & [43] \\
\hline $\begin{array}{c}\text { Vibrio } \\
\text { alginolyticus, Vibrio } \\
\text { parahemolyticus }\end{array}$ & $\begin{array}{l}\text { Marine environment } \\
\text { (Benthic zone) }\end{array}$ & $\begin{array}{l}\text { polyvinyl alcohol-low linear density } \\
\text { polyethylene (PVA-LLDPE) }\end{array}$ & [44] \\
\hline $\begin{array}{c}\text { Proteobacteria } \\
\text { (Caulobacter), Bacter } \\
\text { oides (Dyadobacter). }\end{array}$ & $\begin{array}{l}\text { Microplastic extracted from } \\
\text { the Belgian part of the } \\
\text { North sea. }\end{array}$ & & [45] \\
\hline $\begin{array}{c}\text { Bacillus sp. } \\
\text { Paenibacillus sp }\end{array}$ & Municipal solid waste & Polyethylene (PE) & [46] \\
\hline $\begin{array}{l}\text { Anaerobic marine } \\
\text { consortia }\end{array}$ & Marine litter and water & Polyvinyl chloride (PVC & [47] \\
\hline $\begin{array}{c}\text { Microbulbifer } \\
\text { hydrolyticus IRE-31 }\end{array}$ & $\begin{array}{l}\text { Provided by Sinopec Group } \\
\text { (Beijing, China). }\end{array}$ & Low-density polyethylene (LDPE) & [48] \\
\hline $\begin{array}{l}\text { Citrobacter } s p . \\
\text { Enterobacter } s p\end{array}$ & $\begin{array}{c}\text { Gut of Tenebrio molitor and } \\
\text { Zophobas atratus }\end{array}$ & Polypropylene [PP] & [49] \\
\hline Pseudomonas sp. & $\begin{array}{l}\text { Soil, activated sludge, farm } \\
\text { sludge, and worms. }\end{array}$ & $\begin{array}{c}\text { Polyethylene terephthalate (PET), } \\
\text { High Density Polyethylene (HDPE), } \\
\text { Polyethylene (PE), and PS. }\end{array}$ & {$[50]$} \\
\hline
\end{tabular}


Fungal degradation of plastic

Moreover, fungi also have the ability to stick with micro plastic and they can utilize them. Fungi can help in the production of various chemical bonds in microplastics like carbonyl, ester forming groups and carboxyl by lowering their hydrophobicity. Fungi species have very good reproductive capability. It can enhance the process of transformation and movement of substances [51]. Large varieties of fungi have been investigated in microbial degradation and they have the ability to utilize carbon. In current times, a large number of fungi have been observed that can cause degradation of plastic in the laboratory. Some studies on fungal degradation of plastic are discussed below in the (Table 2).

Table 2. Fungal strains involved in plastic degradation

\begin{tabular}{|c|c|c|c|}
\hline Fungal strain & Environmental source & Microplastic type & Ref. \\
\hline $\begin{array}{c}\text { Penicillium raperi, } \\
\text { Aspergillus flavus }\end{array}$ & $\begin{array}{c}\text { Soil, activated sludge, farm sludge, } \\
\text { and worms. }\end{array}$ & $\begin{array}{c}\text { Polyethylene terephthalate (PET), } \\
\text { High Density Polyethylene } \\
\text { (HDPE), Polyethylene (PE), and } \\
\text { PS. }\end{array}$ & [50] \\
\hline $\begin{array}{c}\text { Aspergillus } \\
\text { tubingensis } \\
\text { (VRKPT) }\end{array}$ & $\begin{array}{c}\text { Costal area } \\
\text { (marine) }\end{array}$ & $\begin{array}{c}\text { High Density Polyethylene } \\
\text { (HDPE) }\end{array}$ & {$[\mathbf{5 2}]$} \\
\hline $\begin{array}{c}\text { Penicillium } \\
\text { simplicissimum } \\
\text { (YK) }\end{array}$ & $\begin{array}{c}\text { Soil and leaved of coastal area } \\
\text { Polyethylene } \\
\text { (PE 500 h with UV) }\end{array}$ & {$[\mathbf{5 3}]$} \\
\hline $\begin{array}{c}\text { Penicillium } \\
\text { pinophilum (ATCC } \\
\text { 11797) }\end{array}$ & $\begin{array}{c}\text { Brought from strain center } \\
\text { (woody plants) }\end{array}$ & $\begin{array}{c}\text { Low Density Polyethylene } \\
\text { (LDPE) }\end{array}$ & {$[\mathbf{5 4}]$} \\
\hline $\begin{array}{c}\text { Aspergillus flavus } \\
\text { PEDX3 }\end{array}$ & Gut of Galleria mellonella & $\begin{array}{c}\text { High-density polyethylene } \\
\text { (HDPE) and Polyethylene (PE) }\end{array}$ & {$[$ [55] } \\
\hline
\end{tabular}

\section{Plastic degradation by contribution of biofilms}

Microplastics get interaction with inorganic molecules, organic substances and microbes in the water [56]. And because of this, various groups and sizes of microbes, which include bacteria, fungi, algae, protists and viruses, adhere to the upper layer of plastics [57]. The settlements of microbes result in the production of biofilms that consist of complicated ecosystems that are made up of microbes, organic and inorganic substances [58]. Microplastic surfaces can act as a base for biofilm development, it has a rough and smooth top layer, low/high densities. It can destroy the morphology and function of microplastics in different ways, secrete degrading enzymes and liberate metabolic byproducts [59].

\section{Mechanism of microbial degradation of plastic}

Microbes exhibit complex enzyme catalyzed chain reactions for degrading plastic. They have a complex network of enzymes to degrade and break down bio-based plastics. Enzymes are released into extracellular space and break down the complex organic compounds of plastic into simplest compounds like water and carbon dioxide.

Complex polymer degraded in three steps by extracellular and intracellular digestion. Synthetic Plastic is first depolymerized in the presence of extracellular depolymerase enzymes followed by mineralization into simpler compounds i.e. $\mathrm{CO} 2$ and $\mathrm{N} 2$ and $\mathrm{H} 2 \mathrm{O}$. Depolymerization of larger polymers into simpler oligomers or monomers makes assimilation easy of plastic products into microbial cells for mineralization. Not every 
enzyme is capable of breaking all types of plastics. There are specific enzymes produced by specific strains for breakdown of one type of plastic. Examples are enlisted in (Table 1). For instance, Protease enzyme is released by Bacillus $s p$ and is used to degrade a specific type of plastic [60].

Mechanism of breakdown of plastic follows four steps:

1. Bio-deterioration

2. Bio fragmentation

3. Assimilation

4. Mineralization

In the first step microbes adhere to plastic polymers and form a thin biofilm on the surface of plastic. then they release EPS which catalyzes the various mechanical degradation reactions. It modifies physical and chemical properties of polymer under varying temperature, drying, $\mathrm{PH}$ and moisture content [61]. Some acids (nitric acid by Nitrobacter) may also be produced by biofilm to disrupt the ultrastructure of plastic polymers. Bio fragmentation will result in the conversion of high molecular weight compounds to low molecular weight compounds i.e., Oligomer, Monomer and dimer by extrinsic factors i.e. biological, Radiations, Chemical and Thermal.
Extracellular and lytic enzymes play a role in degradation by oxygenase, adding oxygen into polymers and destabilizing its structure [62]. Monomers being smaller and simpler can cross walls of bacterial cells and make way for assimilation by bacteria.

Assimilation is the process of utilization and crossing of the membranous barrier by monomers. Monomers present around bacterial cells may not be utilized for energy harvesting so it must be entered into cells for final metabolism. Three ways of monomers breakdown for energy acquisition can be employed i.e. Aerobic, anaerobic respiration and fermentation. Its products are secondary metabolites which undergo mineralization. Final breakdown means complete breakdown of secondary metabolites or hydrolysis of plastic and transform simpler compounds into $\mathrm{Co} 2, \mathrm{~N} 2$ and Water. It is referred as mineralization [63].

Nature of end product influenced by availability of oxygen

Under aerobic conditions, when oxygen is the ultimate final electron acceptor in ETC, the end product of degradation of plastic is $\mathrm{CO}_{2}$ and $\mathrm{H}_{2} \mathrm{O}$ (Fig. 1). Under anaerobic conditions $\mathrm{CO} 2, \mathrm{H} 2 \mathrm{O}$, oxides of Sulphur nitrate and manganese are released [64].

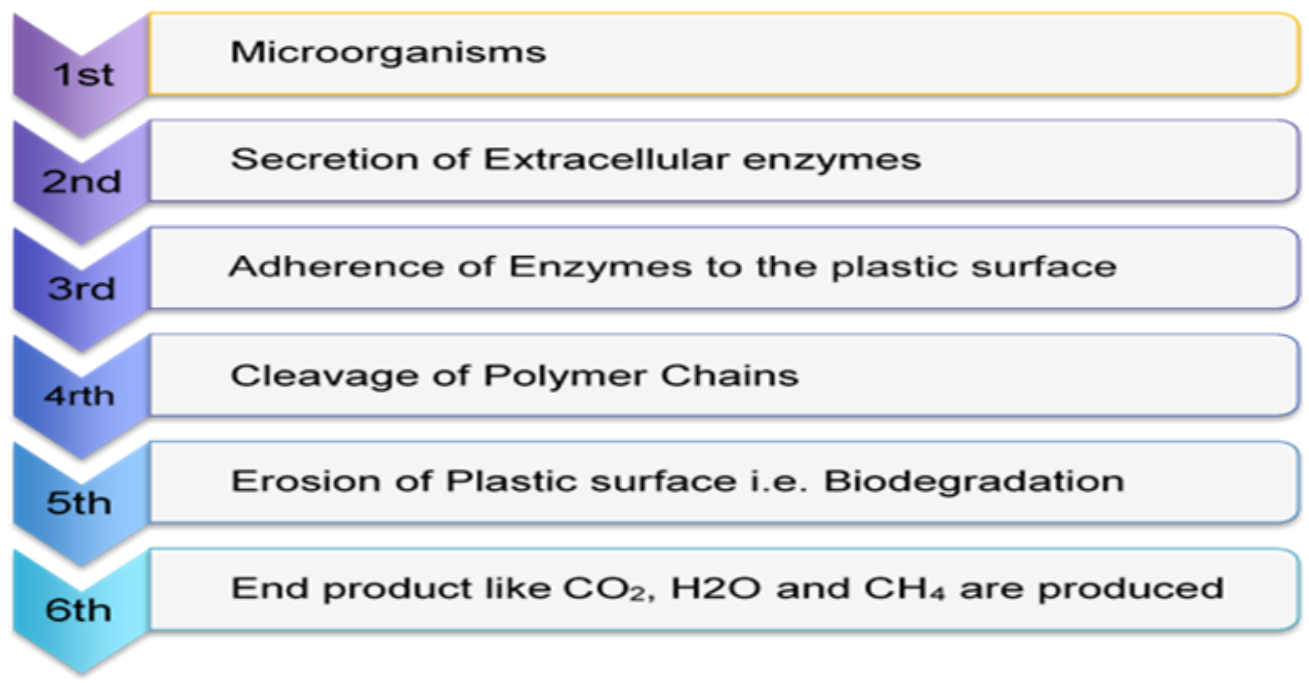

Figure 1. Modification of enzymatic degradation mechanism in plastic [64] Microbial valorization of plastic wastes 
Microbial valorization means usage of microbial degraded plastic to make synthetic chemicals. Depolymerases released by microbes to break down complex polymer oligomers or monomers which are utilized for chemical synthesis [65]. For i.e. conversion of TPA to Succinic Acid, aliphatic hydrocarbons to fatty acids, PHA.

From aromatic hydrocarbons to succinic acids and PHA

Styrene degrades into PHA or Succinic acid in the presence of microbes which exploit styrene as a source of carbon [66]. Pseudomonas putida $\mathrm{CA}-3$ is the microbial species involved in the degradation of polystyrene and it shows that different microbial species are involved in the breakdown of varying types of plastic [67].

\section{Factors affecting plastic biodegradation}

Microbial degradation of plastic is affected by many factors (Fig. 2). Among them the two important factors are the microbial growth and properties of micro plastics in addition to the environment. The physical and chemical properties of plastics comprise of density, crystallinity, molecular weight, structural substances and functional groups [68]. Environmental factors that disturb plastics are heat, humidity, light (Ultra violetUV) and chemicals. It affects the growth and metabolism of microbes, its biomass and degradation ability. Alternatively, an external oxidation environment can introduce aging and it can also hasten the microbial degradation of plastics [69].

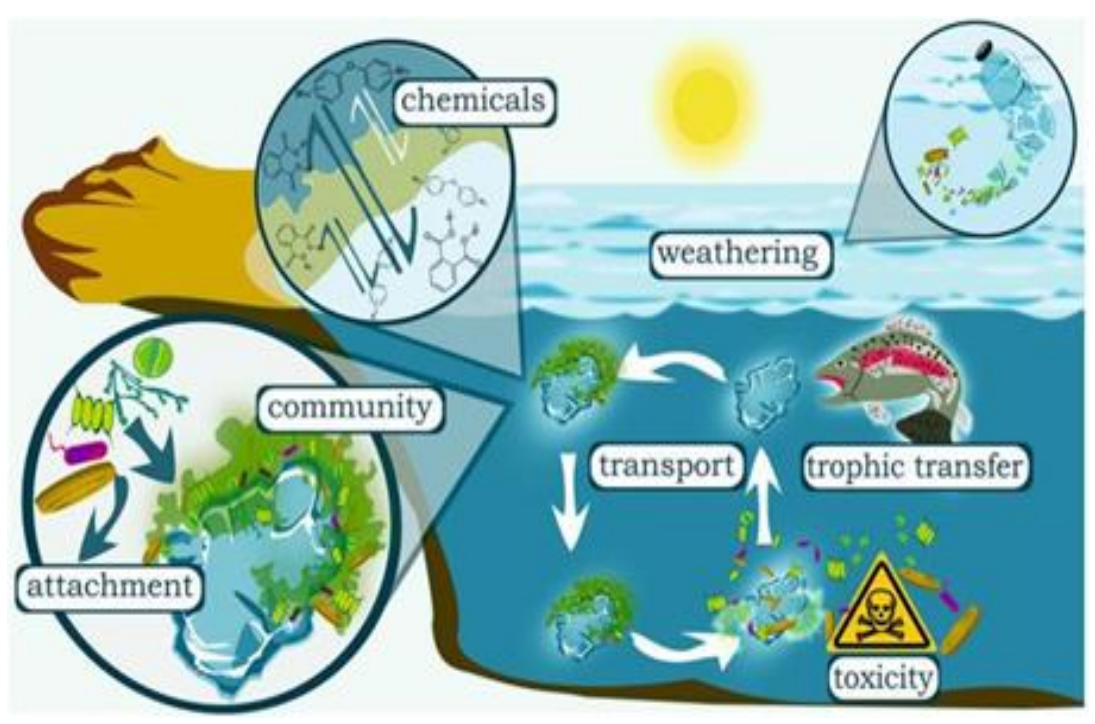

Figure 2. Main steps influencing the changes and potential effects of microplastics that are changed because of biofilms in aquatic environments [70].

Factors affecting plastic degradation rate are enlisted below:

\section{Water availability}

Enzymes produced by microbes work efficiently in the presence of moisture. Activity of enzymes enhances and results in an increase in degradation rate of plastic and speeds up hydrolysis by creating chain scission reactions [71].

\section{PH value}

Hydrogen ion concentration affects the activity of enzymes. It alters the microbial degradation process and products obtained i.e., pH 5 is best working PH for PLA [72, 73].

\section{Molecular weight and size of polymer}

Rate of degradation alters by molecular weight. It is difficult to break polymers of 
higher molecular weight and larger size. Enzyme activity enhances polymers of smaller area and lower molecular weight [72]. It increases chances of direct contact between enzyme and substrate. Lipase degrades polymers of larger size at a slower rate [74]. There exists a standard criterion of shape and size for increasing biodegradability.

\section{Temperature}

Softening temperature is the temperature at which polymers undergo degradation and breakdown into oligomers or diamers. Moreover, the softening temperature means polymers are resistant to biodegradation. Enzymes responsible for degradation may undergo denaturation and loss of integrity at high temperatures. Lipase hydrolyze polycaprolactone (PCL) at lower temperature easily [74].

\section{Enzyme characteristics}

Every enzyme has a unique structure and exhibits specialized catalytic activity for microbial degradation. Small monomers have been degraded easily in the presence of flavus enzymes, while it is unable to break high molecular weight straight chain polyesters [75].

\section{Effect of polymer characteristics Nature of plastic}

Its type determines degradability by microbes. Plastics from petrochemical sources are difficult to decompose because of its hydrophobic non polar nature [76]. Non polar character halts biofilm production and reduces microbial degradation of polyester [77].

\section{Morphological characters}

Polymer morphology has an impact on degradation rate. Amorphous polymers are more susceptible to degradation as compared to crystalline polymers. It's difficult to destroy crystalline arrangements of polymers $[78,79]$.

\section{Environmental factors Additives}

Biodegradable additives are the chemical compounds (dyes, filler) which are added to polymers for catalyzing biodegradation. It expedites the rate of degradation by attracting microbes to polymers. Plastic is not degradable naturally but by adding additives, it can bring change into physical and chemical properties of plastic so it undergoes degradation utilizing microorganism. Addition of filler i.e., lignocellulosic reduces thermal stability so plastic breakdown easily.

\section{Biosurfactants}

Biosurfactants are the chemical compounds which reduce surface tension and change interfacial properties of polymers. It speeds up the rate of biodegradation under unfavorable environmental conditions i.e., extreme temperature or $\mathrm{PH}[\mathbf{8 0}, \mathbf{8 1}]$.

Recent Research on non-biodegradable plastic polyethylene terephthalate (PET) found that various other strains capable of degradation of different plastic have been discovered. Ideonella sakaiensis 201-F6, is the strain which degrades polyethylene terephthalate (PET) into nontoxic methylene oxide and terephthalic acid [82]. Anoxybacillus rupiensis Ir3 (JQ912241) degrades aromatic compounds which are toxic. Pantoea spp. and Enterobacter spp. have the ability to degrade low density polyethylene (LDPE) [83]. These studies help us to find new ways to produce nontoxic eco-friendly biodegradable plastic and novel management strategies.

\section{Conclusion}

In this review article, It is concluded that biodegradable polymers have received much more attention in the last decades due their potential applications in the fields related to environmental protection and the maintenance of physical health. Our environment is rich of potential microorganisms, which can degrade polyester-type biodegradable plastics. These 
microorganisms produce various enzymes i.e. hydrolytic enzymes, which can degrade different types of biodegradable plastics; therefore, such microbes will be helpful in clearing Earth plastic wastes. It is needed to discover new bacterial strains that are capable of degradation. The future outlook for development in the field of biopolymers materials is promising. To improve the properties of biodegradable polymers, variety of methods have been developed. We must encourage the use of biodegradable plastic and say yes to biodegradable plastic that is eco-friendly.

\section{Authors' contributions}

Conceived the idea: S Mazhar, Wrote the paper: S Mazhar, HA Naeem \& M Naheed, Corresponding author: S Mazhar.

\section{Reference}

1. Saminathan P, Sripriya A, Nalini K, Sivakumar T \& Thangapandian V (2014) Biodegradation of plastics by Pseudomonas putida isolated from garden soil samples. J Adv Bot Zool 1(3): 34-38.

2. Zheng Y, Yanful EK \& Bassi AS (2005). A Review of Plastic Waste Biodegradation. Crit Rev Biotechnol 25: 243-250.

3. Vroman I \& Tighzert L (2009). Biodegradable Polymers. Materials 2: 307-344.

4. Sharma M \& Dhingra HK (2016) Poly$\beta$-hydroxybutyrate: a biodegradable polyester, biosynthesis and biodegradation. $\mathrm{Br}$ Microbiol Res J 14(3): 1-11.

5. Vijaya C \& Reddy RM (2008) Impact of soil composting using municipal solid waste on biodegradation of plastics. Indian J Biotechnol 7: 235-239.

6. Tokiwa Y \& Calabia BP (2008). Biological production of functional chemicals from renewable resources. Can J Chem 86(6):548-555.
7. Vona IA, Costana JR, Cantor HA \& Roberts WJ (1965). Manufacture of plastics. New York: Wiley. 141.

8. Noopur M, Sakshi S \& Snnuradha NS (2015). Toxicity and biodegradation of plastics: A review. J Environ Dev 9(3): 906-913.

9. Ghosh SK, Pal S \& Ray S (2013). Study of microbes having potentiality for biodegradation of plastics. Environ Sci Pollut Res 20(7):4339-4355.

10. Krueger MC, Harms H \& Schlosser D (2015). Prospects for microbiological solutions to environmental pollution with plastics. Appl Microbiol Biotechnol 99: 8857-8874.

11. Wackett L \& Hershberger C (2001). Biodegradation and biocatalysismicrobial transformation of organic compounds. ASM Press, Washington, DC

12. Shah AA, Hasan F, Hameed A \& Ahmed, S (2008). Biological degradation of plastics: a comprehensive review. Biotechnol Adv 26: 246-265.

13. Elbanna K, Lutke-Eversloh T, Jendrossek D, Luftmann H \& Steinbuchel A (2004). Studies on the biodegradability of polythioester copolymers and homopolymers by polyhydroxyalkanoate (PHA)-degrading bacteria and PHA depolymerases. Arch Microbiol 182(23):212- 225 .

14. De Tender CA, Devriese LI, Haegeman A, Maes S, Ruttink $T$ \& Dawyndt $P$ (2015). Bacterial community profiling of plastic litter in the Belgian part of the North Sea. Environ Sci Technol 49(16): 9629-9638.

15. Wu CS (2005). A comparison of the structure, thermal properties, and biodegradability of polycaprolactone/chitosan and acrylic acid grafted polycaprolactone/chitosan. Polym 46(1):147-155. 
16. Bakir A, Rowland SJ \& Thompson RC (2014b). Transport of persistent organic pollutants by microplastics in estuarine conditions. Estuar Coast Shelf Sci 140: 14-21.

17. Carr SA, Liu J \& Tesoro AG (2016). Transport and fate of microplastic particles in waste- water treatment plants. Water Res 91: 174-182.

18. Muhamad WNAW, Othman R, Shaharuddin RI \& Irani MS (2015). Microorganism as plastic biodegradation agent towards sustainable environment. Adv Environ Biol 9: 8-14

19. Law KL (2017). Plastics in the marine environment. Annu Rev Mar Sci 9: 205229.

20. Duis K \& Coors A (2016). Microplastics in the aquatic and terrestrial environment: sources (with a specific focus on personal care products), fate and effects. Environ Sci Eur 28: 2.

21. Eerkes-Medrano D, Thompson RC \& Aldridge DC (2015). Microplastics in freshwater sys- tems: a review of the emerging threats, identification of knowledge gaps and prioritisation of research needs. Water Res 75: 63-82.

22. Van Cauwenberghe L, Devriese L, Galgani F, Robbens J \& Janssen CR (2015). Microplastics in sediments: a review of techniques, occurrence and effects. Mar Environ Res 111: 5-17.

23. Chua ASM, Takabatake H, Satoh H \& Mino $T$ (2003). Production of polyhydroxyalkanoates (PHA) by activated sludge treating municipal waste water: Effect of $\mathrm{pH}$, Sludge Retention Time. Water Res 37(15): 3602-3611.

24. Pavani P \& Rajeswari TR (2014). Impact of plastics on environmental pollution. $J$ Chem Pharm 3: 87-93.

25. Haward M (2018). Plastic pollution of the world's seas and oceans as a contemporary challenge in ocean governance. Nat Commun 9(1): 667.
26. Usha R, Sangeetha T \& Palaniswamy M (2011). Screening of Polyethylene degrading Microorganisms from Garbage Soil. Libyan Agric Res Cen J Intl 2 (4): 200-204.

27. Rudel RA, Attfield KR, Schifano JN \& Brody JG (2007). Chemicals causing mammary gland tumors in animals signal new directions for epidemiology, chemicals testing and risk assessment for breast cancer prevention. Cancer 109(1): 2635-2666.

28. Gray J, Evans N, Taylor B, Rizzo, JJ \& Walker M (2009). State of the evidence: The connection between Breast Cancer and the Environment. Int J Occu Environ Heal 15(1): 43-78.

29. Huff J \& Infante PF (2011). Styrene exposure and risk of cancer. Mutagenesis 26(5): 583-584.

30. Benachour N \& Aris A (2009). Toxic effects of low doses of bisphenol-a on human placental cells. Toxicol Appl Pharmacol 241(3): 322-328.

31. Hao J, Wang J, Zhao W, Ding L, Gao E \& Yuan W (2011). Effect of bisphenol an exposure on sex hormone level in occupational women. Wei Sheng Yan Jiu 40(3): 312-314.

32. Brooks AN, Turkarslan S, Beer KD, Lo FY \& Baliga NS (2011). Adaptation of cells to new environments. Wiley Interdiscip. Rev Syst Biol Med 3: 544561.

33. Qi X, Ren Y \& Wang X (2017). New advances in the biodegradation of poly(lactic) acid. Int Biodeterior Biodegrad 117: 215-223.

34. Gu JD (2003). Microbiological deterioration and degradation of synthetic polymeric ma- terials: recent research advances. Int Biodeterior Biodegrad 52: 69-91.

35. Ammala A, Bateman S, Dean $\mathrm{K}$, Petinakis E, Sangwan P, Wong S, Yuan Q, Yu L, Patrick C \& Leong KH (2011). 
An overview of degradable and biodegradable polyole-fins. Prog Polym Sci 36: 1015-1049.

36. Rujnic-Sokele M \& Pilipovic A (2017). Challenges and opportunities of biodegradable plastics: a mini review. Waste Manag Res 35: 132-140.

37. Bakir A, Rowland SJ \& Thompson RC (2014a). Enhanced desorption of persistent organic pollutants from microplastics under simulated physiological conditions. Environ Pollut 185: 16-23.

38. Janssen PH, Yates PS, Grinton BE, Taylor PM \& Sait M (2002). Improved culturability of soil bacteria and isolation in pure culture of novel members of the divisions Acidobacteria, Actinobacteria, Proteobacteria, and Verrucomicrobia. Appl Environ Microbiol 68: 2391-2396.

39. Auta HS, Emenike CU, Jayanthi B \& Fauziah SH (2018). Growth kinetics and biodeterioration of polypropylene microplastics by Bacillus sp. and Rhodococcus sp. isolated from mangrove sediment. Mar Pollut Bull 127: 15-21.

40. Auta HS, Emenike CU \& Fauziah SH (2017). Screening of Bacillus strains isolated from mangrove ecosystems in Peninsular Malaysia for microplastic degradation. Environ. Pollut 231: 15521559.

41. Yang J, Yang Y, Wu WM, Zhao J \& Jiang L (2014). Evidence of polyethylene biodegradation by bacterial strains from the guts of plastic-eating waxworms. Environ Sci Technol 48: 13776-13784.

42. Paco A, Duarte K, da Costa JP, Santos PS, Pereira R, Pereira ME, Freitas AC, Duarte AC \& Rocha-Santos TA (2017). Biodegradation of polyethylene microplastics by the marine fungus Zalerion maritimum. Sci Total Environ 586: 10-15.

43. Sekiguchi T, Sato T, Enoki M, Kanehiro H, Uematsu K \& Kato C (2010). Isolation and characterization of biodegradable plastic degrading bacteria from deep-sea environments. JAMSTEC-R 11:33-41

44. Raghul SS, Bhat SG, Chandrasekaran M, Francis V \& Thachil ET (2014). Biodegradation of polyvinyl alcohol-low linear density polyethylene-blended plastic film by consortium of marine benthic vibrios. Int J Environ Sci Technol 11(7):1827-1834

45. De Tender CA, Devriese LI, Haegeman A, Maes S, Ruttink $\mathrm{T}$ \& Dawyndt $\mathrm{P}$ (2015). Bacterial community profiling of plastic litter in the Belgian part of the North Sea. Environ Sci Technol 49(16): 9629-9638.

46. Park SY \& Kim CG (2019). Biodegradation of micro-polyethylene particles by bacterial colonization of a mixed microbial consortium isolated from a landfill site. Chemosphere 222: 527-533.

47. Giacomucci L, Raddadi N, Soccio M, Lotti N \& Fava F (2020). Biodegradation of polyvinyl chloride plastic films by enriched anaerobic marine consortia. Mar Environ Res 158: 104949.

48. Li Z, Wei R, Gao M, Ren Y, Yu B, Nie K \& Liu L (2020). Biodegradation of lowdensity polyethylene by Microbulbifer hydrolyticus IRE-31. J Environ Manage 263: 110402.

49. Yang SS, Ding MQ, He L, Zhang CH, Li QX, Xing DF \& Wu WM (2021). Biodegradation of polypropylene by yellow mealworms (Tenebrio molitor) and superworms (Zophobas atratus) via gut-microbe-dependent depolymerization. Sci Total Environ 756: 144087.

50. Taghavi N, Singhal N, Zhuang WQ \& Baroutian S (2021). Degradation of plastic waste using stimulated and naturally occurring microbial strains. Chemosphere 263: 127975. 
51. Chen Y, Stemple B, Kumar M \& Wei N (2016). Cell surface display fungal laccase as a re- newable biocatalyst for degradation of persistent micropollutants bisphenol A and sulfamethoxazole. Environ Sci Technol 50: 8799-8808.

52. Devi RS, Kannan VR, Nivas D, Kannan K, Chandru S \& Antony AR (2015). Biodegradation of HDPE by Aspergillus spp. from marine ecosystem of Gulf of Mannar, India. Mar Pollut Bull 96: 32 40.

53. Yamada-Onodera $\mathrm{K}$, Mukumoto $\mathrm{H}$, Katsuyaya Y, Saiganji A \& Tani Y (2001). Degradation of polyethylene by a fungus, Penicillium simplicissimum YK. Polym Degrad Stab 72: 323-327.

54. Volke-Sepúlveda T, Saucedo-Castaneda G, Gutierrez-Rojas M, Manzur A \& Favela-Torres, E (2002). Thermally treated low density polyethylene biodegradation by Penicillium pinophilum and Aspergillus niger. J Appl Polym Sci 83: 305-314.

55. Zhang J, Gao D, Li Q, Zhao Y, Li L, Lin H \& Zhao Y (2020). Biodegradation of polyethylene microplastic particles by the fungus Aspergillus flavus from the guts of wax moth Galleria mellonella. Sci Total Environ 704: 135931.

56. Parrish K \& Fahrenfeld NL (2019). Microplastic biofilm in fresh- and wastewater as a function of microparticle type and size class. Environ Sci Water Res Technol 5: 495-505.

57. Oberbeckmann S, Loder MGJ \& Labrenz M (2015). Marine microplasticassociated biofilms -a review. Environ Chem 12.

58. Flemming HC (1997). Relevance of Biofilms for the Biodeterioration of Surfaces of Polymeric materials. Pol Degrad Stab 59(1-3): 309-315

59. Miao L, Wang P, Hou J, Yao Y, Liu Z, Liu S \& Li T (2019). Distinct community structure and microbial functions of biofilms colonizing microplastics. Sci Total Environ 650: 2395-2402.

60. Sivan A (2011). New perspectives in plastic biodegradation. Curr Opin Biotechnol 22(3): 422-426.

61. Bonhomme S, Cuer A, Delort AM, Lemaire J, Sancelme M \& Scott G (2003). Environmental biodegradation of polyethylene. Polym Degrad Stab 81: 441-452.

62. Lugauskas A, Levinskait L \& Peciulyte D (2003). Micromycetes as deterioration agents of polymeric materials. Int Biodeter Biodegrad 52: 233-242.

63. Tokiwa Y, Calabia BP, Ugwu CU \& Aiba S (2009). Biodegradability of plastics. Int J Mol Sci 10(9): 3722-3742.

64. Priyanka N \& Archana T (2011). Biodegradability of polythene and plastic by the help of microorganism: a way for brighter future. $J$ Environ Anal Toxicol 1(4): 1000111.

65. Wierckx N, Prieto MA, Pomposiello P, de Lorenzo V, O’Connor K \& Blank LM (2015). Plastic waste as a novel substrate for industrial biotechnology. Microb Biotechnol 8: 900-903.

66. O'Leary ND, O'Connor KE, Goff M \& Dobson AD (2002). Biochemistry, genetics and physiology of microbial styrene degradation. FEMS Microbiol Rev 26: 403-417.

67. Ward PG, de Roo G \& O'Connor KE (2005). Accumulation of polyhydroxyalkanoate from styrene and phenylacetic acid by Pseudomonas putida CA-3. Appl Environ Microbiol 71: 2046-2052.

68. Shah AA, Hasan F, Hameed A \& Ahmed $S$ (2008). Biological degradation of plastics: a comprehensive review. Biotechnol Adv 26: 246-265.

69. Krueger MC, Harms H, Schlosser D (2015). Prospects for microbiological solutions to environmental pollution with 
plastics. Appl Microbiol Biotechnol 99(21): 8857-8874.

70. Rummel CD, Jahnke A, Gorokhova E, Kuhnel D \& Schmitt-Jansen M (2017). Impacts of biofilm formation on the fate and potential effects of microplastic in the aquatic environment. Environ Sci Technol Lett

71. Ho KLG, Pometto AL, Gadea-Rivas A, Briceno JA \& Rojas A (1999). Degradation of polylactic acid (PLA) plastic in Costa Rican soil and Iowa state university compost rows. $J$ Environ Polym Degrad 7(4): 173-177.

72. Auras R, Harte B \& Selke S (2004). An overview of polylactides as packaging materials. Macromol Biosci 4: 835-864.

73. Henton DE, Gruber P, Lunt J \& Randall J (2005) Polylactic acid technology. In Natural fibers, biopolymers and biocomposites ed. Mohanty, A.K., pp 528-569. Boca Raton, FL: CRC Press.

74. Tokiwa Y, Calabia BP, Ugwu CU \& Aiba S (2009). Biodegradability of plastics. Int J Mol Sci 10(9): 3722-3742.

75. Kale G, Kijchavengkul T, Auras R, Rubino M, Selke SE \& Singh SP (2007). Compostability of bioplastic packaging materials: an overview. Macromol Biosci 7(3): 255-277.

76. Yamada-Onodera $\mathrm{K}$, Mukumoto $\mathrm{H}$, Katsuyaya Y, Saiganji A \& Tani Y (2001). Degradation of polyethylene by a fungus, Penicillium simplicissimum YK. Polym Degrad Stab 72(2): 323-327.

77. Hadad D, Geresh S \& Sivan A (2005). Biodegradation of polyethylene by the thermophilic bacterium Brevibacillus borstelensis. J Appl Microbiol 98(5): 1093-1100.

78. Iwata T \& Doi Y (1998). Morphology and enzymatic degradation of poly (Llactic acid) single crystals. Macromol (31): 2461-2467.

79. Tsuji H \& Miyauchi S (2001). Poly(Llactide) Effects of crystallinity on enzymatic hydrolysis of poly(1-lactide) without free amorphous region. Polym Degrad Stab (71): 415-424.

80. Kawai F, Watanabe M, Shibata M, Yokoyama S \& Sudate Y (2002). Experimental analysis and numerical simulation for biodegradability of polyethylene. Polym Degrad Stab 76(1): 129-135.

81. Kawai F, Watanabe M, Shibata M, Yokoyama S, Sudate Y \& Hayashi S (2004). Comparative study on biodegradability of polyethylene wax by bacteria and fungi. Polym Degrad Stab 86(1): 105-114.

82. Yoshida S, Hiraga K, Takehana T, Taniguchi I, Yamaji H, Maeda Y, Toyohara K, Miyamoto K, Kimura Y \& Oda K (2016) A bacterium that degrades and assimilates poly (ethylene terephthalate). Sci 351(6278):11961199.

83. Skariyachan S, Manjunatha V, Sultana S, Jois C, Bai V \& Vasist KS (2016). Novel bacterial consortia isolated from plastic garbage processing areas demonstrated enhanced degradation for low density polyethylene. Environ Sci and Poll Res 23(18): 18307-18319. 